\title{
Tracking young-of-the-year gray seals Halichoerus grypus to estimate fishery encounter risk
}

\author{
Kimberly T. Murray ${ }^{1, *}$, Joshua M. Hatch ${ }^{1}$, Robert A. DiGiovanni Jr. ${ }^{2}$, \\ Elizabeth Josephson ${ }^{3}$
}

\author{
${ }^{1}$ NOAA Northeast Fisheries Science Center, Woods Hole, Massachusetts 02543, USA \\ ${ }^{2}$ Atlantic Marine Conservation Society, Hampton Bays, New York 11946, USA \\ ${ }^{3}$ Integrated Statistics Inc, Woods Hole, Massachusetts 02543, USA
}

\begin{abstract}
The current level of annual incidental bycatch of gray seals Halichoerus grypus in the New England sink gillnet fishery is the highest for all marine mammal species in the USA. One way to evaluate the risk of bycatch is to examine the risk of encounter between an animal and fishing gear based on the animal's habitat use in relation to fishing activity. Here we used satellite telemetry deployed on 30 gray seal pups in 2019 and 2020 to measure the risk of encounter with large-mesh sink gillnet fishing effort throughout the Gulf of Maine and southern New England. We estimated relative encounter risk within 30 min grid cells in each calendar quarter based on the overlap of seal presence and fishing effort, and then validated the expected risk based on bycatch events reported by independent observers on board fishing vessels. The relative risk of seals encountering gillnet fishing gear was highest off southeastern Massachusetts in spring. Patterns in the estimated encounter risk fit our expectation that relatively high levels of habitat use and fishing effort correspond to increased encounter risk. The approach taken here can be used to identify times and areas of high encounter risk to justify altered fishing practices for purposes of avoidance, or to target observer monitoring intended to characterize and quantify bycatch. Mitigation strategies will need to be continuously monitored and updated to incorporate new information as conflicts with fisheries and gray seals are likely to continue.
\end{abstract}

KEY WORDS: Gray seal $\cdot$ Satellite telemetry $\cdot$ Bycatch $\cdot$ Sink gillnet $\cdot$ Encounter risk

\section{INTRODUCTION}

As some protected wildlife populations recover or expand throughout their range, conflicts with commercial and recreational fisheries have increased (Larson et al. 2013, Cook et al. 2015, Cosgrove et al. 2016, Olsen et al. 2018). Animals may prey upon target catch (Rafferty et al. 2012, Peterson \& Carothers 2013, Cosgrove et al. 2015), and damage or become entangled in fishing gear (Kauppinen et al. 2005, Moore et al. 2009). These direct interactions can incur significant economic costs to fishermen (Gil-

*Corresponding author: kimberly.murray@noaa.gov man et al. 2008, Gandini \& Frere 2012), and are detrimental to the animals' welfare. Furthermore, fisheries interactions may impact population growth depending on life history characteristics of the species (Lewison et al. 2004), the age classes affected by bycatch (Wallace et al. 2008), and the spatial scale of bycatch (Anderson et al. 2018). To help reduce depredation or bycatch and avoid costly interactions, fishermen have used deterrents, adjusted fishing locations, and modified gear (see Tixier et al. 2021 for a review).

In the Northwest Atlantic, gray seals Halichoerus grypus have been recolonizing parts of their former

(C) R. A. DiGiovanni Jr., E. Josephson, and outside the USA, the US Government 2021. Open Access under Creative Commons by Attribution Licence. Use, distribution and reproduction are unrestricted. Authors and original publication must be credited.

Publisher: Inter-Research · www.int-res.com 
range in US waters following passage of the Marine Mammal Protection Act (MMPA) of 1972 (Wood et al. 2020). Concurrent with recolonization, interactions between gray seals and commercial fishing effort have increased (Johnston et al. 2015, Orphanides \& Hatch 2017, Orphanides 2019, 2020). Seals drown in gillnets, or break free and live with life-threatening entanglements (Martins et al. 2019), while fishermen experience catch loss, damage to fishing gear, and additional direct/indirect costs (Gruber 2014). The current level of annual incidental bycatch of gray seals in the New England sink gillnet fishery is the highest of all marine mammal species/stocks in the USA (Hayes et al. 2019, Muto et al. 2020, Carretta et al. 2020). In 2017, an estimated total of 930 gray seals were lethally bycaught in the New England sink gillnet fishery (Orphanides 2020), which is roughly $14 \%$ of total US pup production (den Heyer et al. 2021). Many animals are also seen living with serious entanglements that will likely result in a mortality, so actual bycatch may be higher than previously estimated (Martins et al. 2019). Solutions are needed to reduce bycatch to spare fishermen from unnecessary gear damage and potential economic losses. This would also confer animal welfare benefits and help minimize resources spent on responding to stranded and entangled animals.

The gray seal population in the western North Atlantic ranges from the northern Gulf of St Lawrence to New Jersey, USA, and is considered a single population based on genetic evidence (Wood et al. 2011). In 2016 at pupping colonies in the Gulf of Maine, Scotian Shelf, and Gulf of St. Lawrence, female gray seals produced roughly 109000 pups, 6\% of which were born in the USA compared to the $80 \%$ of produced at Sable Island, Canada (den Heyer et al. 2021). Increased rates of pupping at US sites between 1988 and 2019, combined with the presence of branded females from Sable Island, suggest that seals are recruiting to US colonies from larger pupping colonies in Canada (Wood et al. 2020). These apparent increases in immigration of animals to the area may mask the effect of bycatch on the US portion of the gray seal population.

Studying an animal's habitat use relative to commercial fishing spatiotemporal activity can be an important predictor of bycatch risk (Goldsworthy \& Page 2007, Grech et al. 2008, Murray \& Orphanides 2013, Hatch et al. 2016, Cronin et al. 2016, Stepanuk et al. 2018, Baird et al. 2021). Though spatiotemporal overlap may not necessarily lead to bycatch events, it could be a good indicator of encounter risk. Other factors influencing bycatch occurrence include the animals' diving and surfacing behavior, as well as their behavior around fishing gear (Königson et al. 2013, Cronin et al. 2016). Data collected by fisheries observers are also used to evaluate the magnitude and distribution of bycatch rates (Murray 2009, Rossman 2010, Warden 2011, Hatch 2018). However, assessing risk via observer monitoring requires a sufficient level of observer effort, deployed randomly such that it is a representative sample of commercial effort (Cahalan \& Faunce 2020, Curtis \& Carretta 2020). Often, observer coverage may be constrained in scale or distribution due to practical reasons (limited funds, observers, etc.), and so may not fully represent potential interactions between animals and fishing gear.

Understanding the habitat use and behavior of young-of-the-year gray seals may help reduce interactions with fishing gear. Gray seals give birth to their pups from December to February. After a 3 wk lactation period, females mate and then disperse with other adults from the colonies. Weanlings remain on the colonies for a land-based post-weaning fast of 10 to $40 \mathrm{~d}$ before departing to sea (Fedak \& Anderson 1982). Pups need to forage successfully before endogenous fuel reserves are depleted (Bennett et al. 2010), so spending time in profitable foraging areas likely increases their chance of survival. After dispersing from the colonies, many young gray seals die or become entangled in fishing nets. Almost all of the documented bycatch is young-of-the-year animals, perhaps reflecting more naiveté around nets and/or lack of strength to break through the net monofilament compared to adults.

In this paper, we use pup telemetry to quantify quarterly estimates of spatial distribution once pups depart natal colonies and begin foraging independently. We targeted pups on natal colonies for tagging during the January to February birthing months, and followed young-of-the-year individuals throughout the weaning transition and their first season of independent foraging in the marine environment. Given the significant mortality levels associated with this demographic in gillnet fisheries, we designed analyses to identify areas of high, medium, and low overlap between seal habitat use and spatially explicit fishing activity. We validated levels of expected risk through actual observations of bycatch collected via fishery observer programs. Results of this analysis identify hotspots where interactions are common and could justify altered fishing practices for purposes of avoidance, as well as times and areas for focused monitoring of gray seal bycatch. 


\section{MATERIALS AND METHODS}

\subsection{Seal movements}

During the last 2 wk of January 2019 and 2020, we attached satellite tags (Wildlife Computers, SPLASH and SPOT models) to 30 gray seal pups (16 females, 14 males) at 3 different pupping colonies (see Fig. 1, Table 1). We randomly selected weaned pups that had molted most if not all of their newborn (lanugo) fur, and inferred these pups to be at least 3 to $4 \mathrm{wk}$ old (Bowen et al. 2003). Following capture, we weighed pups and then restrained them without sedation to collect measurements and affix tags. We secured each satellite tag to the fur on the back of the neck with 5 min quick-set Devcon epoxy, and we also tagged each hind flipper with an Allflex tag. We programmed the satellite tags to begin transmitting once the animal entered the water. Transmissions paused when the seal was hauled-out, defined as being $50 \%$ dry for 5 consecutive minutes. Tags did not transmit between 04:00 and 07:00 h, or 17:00 and 18:00 $h$, because satellites were not over the study area at those times.

\subsection{Seal marine habitat use}

We fit a Continuous Time Correlated Random Walk (CTCRW) movement model (Johnson et al. 2008) to telemetered geolocations of seal pups using only location classes B and above (Vincent et al. 2002) filtered by a maximum speed assumption of $5 \mathrm{~km} \mathrm{~h}^{-1}$ (McConnell et al. 1992, Johnson et al. 2008). We then interpolated hourly locations from the fitted CTCRW model for each individual, except when time gaps between fitted locations were greater than $3 \mathrm{~d}$.

To normalize for varying tag durations, we weighted each hourly interpolated position by the inverse of the number of individuals that had position estimates for the same relative track day (Roe et al. 2014):

$$
w_{t i}=1 / n_{t}
$$

where $w_{t i}$ is the weight for the $t$ th location estimate on the $i$ th individual's track, and $n_{t}$ is the number of individuals with a $t$ th location estimate. We then intersected these weighted positions with $30 \mathrm{~min}$ grid cells (approximately $2420 \mathrm{~km}^{2}$ ) and summed positions in each cell for each calendar quarter. Next we computed the relative probability $\left(P_{\text {rel }}\right)$ that a seal occupied a grid cell $i$ in quarter $t$ relative to all other cells across all quarters (Roe et al. 2014) based on the density of positions within a cell:

$$
P_{\text {rel }}(\text { seal })_{i t}=\frac{\text { density }_{i t}}{\sum_{i=1}^{n} \sum_{t=1}^{4} \text { density }_{i t}}
$$

with values that can range between 0 (low) and 1 (high).

We conducted all analyses in $\mathrm{R}(\mathrm{v}$ 3.6.0, R Core Development Team).

\subsection{Commercial gillnet effort}

Mandatory Vessel Trip Reports (VTRs) completed by commercial gillnet fishermen in US waters during 2015-2019 provided a measure of total fishing effort (see Table S1 in the Supplement at www.int-res.com/ articles/suppl/m671p235_supp.pdf). We did not have data on gillnet effort in Canadian waters to evaluate encounter risk with fishing gear when seals left US waters. Only those trips fishing with meshes $>20 \mathrm{~cm}$ were examined because gray seal bycatch occurs primarily in this mesh size (Orphanides 2020). Fishermen are instructed to report the location of the start of haul back for the string with the most panels; we used this location to represent the entire trip, which typically lasts $1 \mathrm{~d}$. The length of a gillnet string on a trip fishing with large mesh ranged from $<0.5$ to $2.2 \mathrm{~km}$, well within the size of the grid cells used in this analysis.

We intersected each reported fishing location with the same 30 min grid cells used to define the relative probability of seal occupancy, and then summed the number of trips in each grid cell for each calendar quarter. Next we computed the relative probability that fishing effort (expressed as number of trips) occupied a grid cell $i$ in quarter $t$ relative to all other cells across all quarters (Roe et al. 2014):

$$
P_{\text {rel }}\left(\text { effort }_{i t}=\frac{\text { effort }_{i t}}{\sum_{i=1}^{n} \sum_{t=1}^{4} \text { effort }_{i t}}\right.
$$

with values that can range between 0 (low) and 1 (high).

\subsection{Seal use and fishing effort overlap}

We computed 2 different indices to measure the degree to which seals and fishing effort overlap. We used the Morisita Horn Index $\left(C_{\mathrm{MH}}\right)$ to estimate the spatial overlap of seals and fisheries, because this index has been used to measure overlap with tagged gray seals and similar set net fisheries in Irish waters 
(Cronin et al. 2016). We also computed an Encounter Risk (ER) index (Roe et al. 2014), to be able to map estimated risk both spatially and temporally.
The Morisita Horn Index is defined as:

$$
C_{\mathrm{MH}}=\frac{2 \sum P_{f} P_{s}}{\sum P_{f}^{2}+\sum P_{S}^{2}}
$$

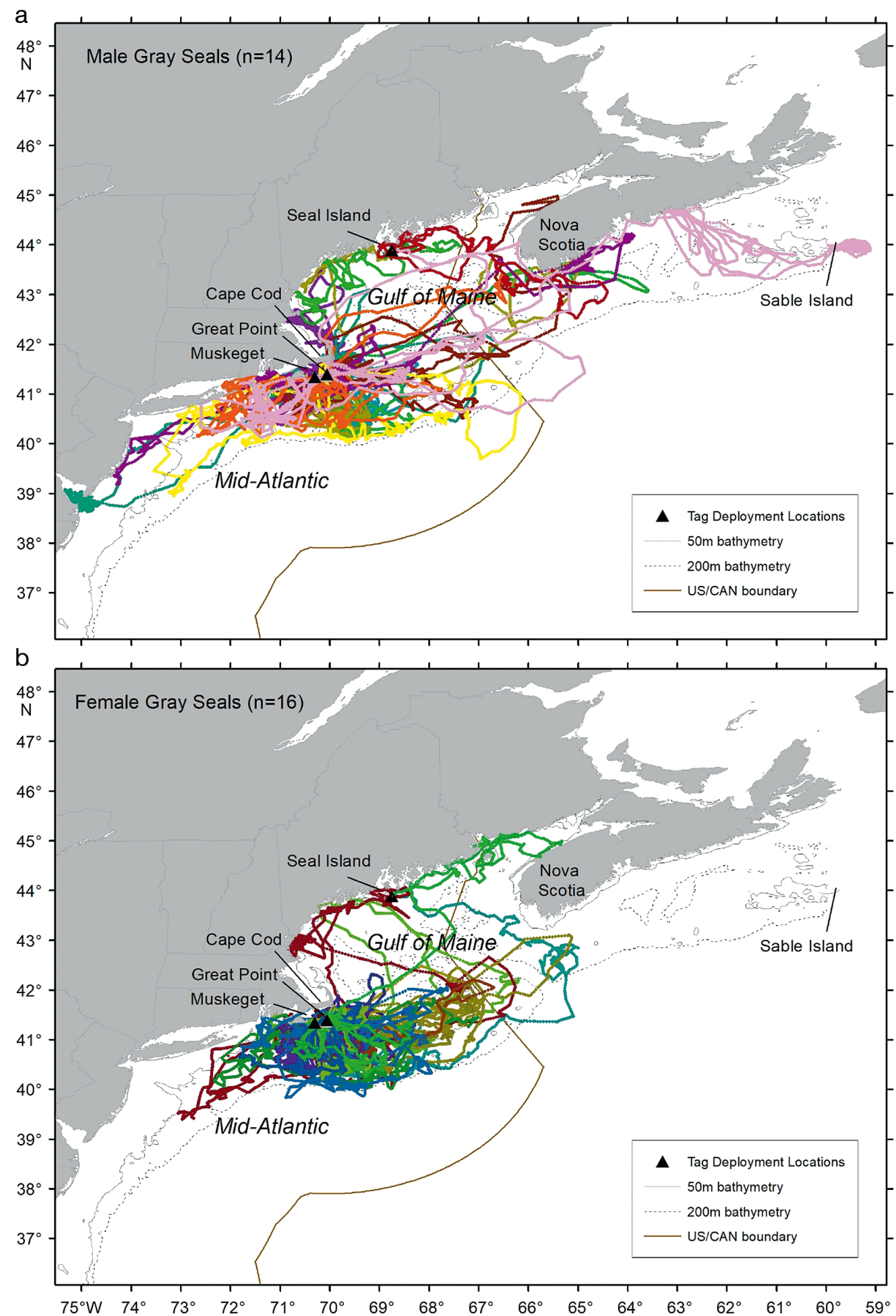

Fig. 1. Interpolated telemetry tracks from (a) 14 male gray seal pups and (b) 16 female gray seal pups, 2019-2020 
where $P_{\mathrm{f}}$ is the proportion of fishing effort and $P_{\mathrm{s}}$ is the proportion of seal use in each grid cell. Low values of $C_{\mathrm{MH}}$ suggest low overlap. To account for spatial autocorrelation, we used a local Moran's $I$ to group grid cells into 4 regions of similar $P_{\mathrm{f}} P_{\mathrm{s}}$ values based on proximity to adjacent cells. We then permuted the grid cells within each region 10000 times and computed the $C_{\mathrm{MH}}$ for each permutation, in order to test the hypothesis that the observed value of $C_{\mathrm{MH}}$ was significantly different ( $\mathrm{p} \leq 0.05)$ from the $C_{\mathrm{MH}}$ index calculated assuming complete spatial randomness with regional partitions.

We also computed a relative ER measure in each grid cell to map overlap in time and space. To do this, we combined the relative probabilities of fishing effort $P_{\text {rel }}$ (effort) and seal use $P_{\text {rel }}$ (seal) in each grid cell $i$ in quarter $t$ relative to all other cells across all quarters and computed the Encounter Risk (ER) as:

$$
P_{\text {rel }}(\mathrm{ER})_{i t}=\frac{P_{\text {rel }}(\text { seal })_{i t} \times P_{\text {rel }}(\text { effort })_{i t}}{\sum_{i=1}^{n} \sum_{t=1}^{4} P_{\text {rel }}(\text { seal })_{i t} \times P_{\text {rel }}(\text { effort })_{i t}}
$$

The encounter risk indices were grouped into 3 risk categories, based on the quartiles of $P_{\text {rel }}(\mathrm{ER})$, as follows: 'Low' $\left(P_{\text {rel }} \leq 0.00004\right)$ (1st quartile); 'Medium' $\left(0.00004>P_{\text {rel }} \leq 0.003\right)$ (2nd and 3rd quartiles); and 'High' $\left(P_{\text {rel }}>0.003\right)$ (4th quartile).

To investigate whether a seal's susceptibility to bycatch risk may be related to an individual's disproportional use of space, we investigated the proportion of time each individual seal spent in high/medium/ low risk areas. bootstrap resampling procedure to calculate a tau correlation statistic with $95 \%$ confidence intervals. We generated 1000 bootstrap replicates of the correlation between the observed bycatch rates and encounter risk by resampling the grid cells for each quarter. The $95 \%$ CI for the correlation statistic was computed from the upper $97.5 \%$ and lower $2.5 \%$ quartiles of the bootstrap replicates.

For each quarter, we also mapped the observed bycatch in each grid cell, and tallied the number of observed bycatch events in each risk category.

\section{RESULTS}

\subsection{Animal movement data and habitat use}

The satellite tags transmitted from 4 to $287 \mathrm{~d}$, with seals travelling total distances of 54 to $11719 \mathrm{~km}$ (Table 1, Fig. 1, see Table S2 in the Supplement). The seals ranged as far south as Delaware Bay and as far north as Sable Island, Canada. Not accounting for varying tag durations, on average seals spent $8 \%$ of their time in Canadian waters, with 1 seal spending almost $50 \%$ of its time in Canadian waters.

From January to June, seals utilized large portions of the Gulf of Maine and Mid-Atlantic, with areas of high use to the south and east of Cape Cod (Fig. 2). From July to December, seals spent relatively less time in the Mid-Atlantic and more time around eastern Nova Scotia and Sable Island. However, in the last quarter, only 2 tags continued to transmit up to mid-November, so data for this quarter were relatively scarce.

\subsection{Encounter risk validation}

We used data from observers on board commercial gillnet vessels from 2015 to 2019 to validate our metrics of encounter risk in comparison to actual bycatch events. First, we used a non-parametric Kendall's tau correlation test to evaluate whether there was a significant relationship $(p \leq 0.05)$ between bycatch rates and risk level. A significant relationship would indicate that the estimated risk level was associated with the observed bycatch rates, which accounts for varying amounts of observer coverage levels. We used a
Table 1. Gray seal satellite tag deployment summary, 2019 and 2020

\begin{tabular}{|lrrrrr|}
\hline & \multicolumn{5}{c|}{ Deployment location } \\
\cline { 2 - 6 } & $\begin{array}{c}\text { Massachusetts } \\
\text { (Muskeget \& }\end{array}$ & $\begin{array}{c}\text { Maine } \\
\text { (Seal Island) }\end{array}$ & $\begin{array}{c}\text { All } \\
\text { animals }\end{array}$ \\
& Great Point) & & & \\
\hline Sex (n) & $\mathrm{F}(13)$ & $\mathrm{M}(10)$ & $\mathrm{F}(3)$ & $\mathrm{M}(4)$ & \multicolumn{1}{c|}{30} \\
Mean weight $(\mathrm{kg})$ & 36.5 & 42.3 & 35.4 & 40.7 & 39.1 \\
SD & 5.4 & 7.6 & 11.8 & 8.2 & 7.3 \\
Mean length $(\mathrm{cm})$ & 105.0 & 112.0 & 101.3 & 107.6 & 107.6 \\
SD & 6.9 & 11.0 & 9.1 & 5.9 & 8.9 \\
Mean tag duration $(\mathrm{d})$ & 121.0 & 151.0 & 161.0 & 144.5 & 138.1 \\
SD & 70.7 & 65.0 & 66.3 & 101.9 & 70.7 \\
Mean distance travelled $(\mathrm{km})$ & 3683.8 & 4581.8 & 5148.7 & 5308.0 & 4346.2 \\
SD & 2133.4 & 1743.5 & 1453.2 & 4542.6 & 2348.8 \\
& & & & & \\
\hline
\end{tabular}




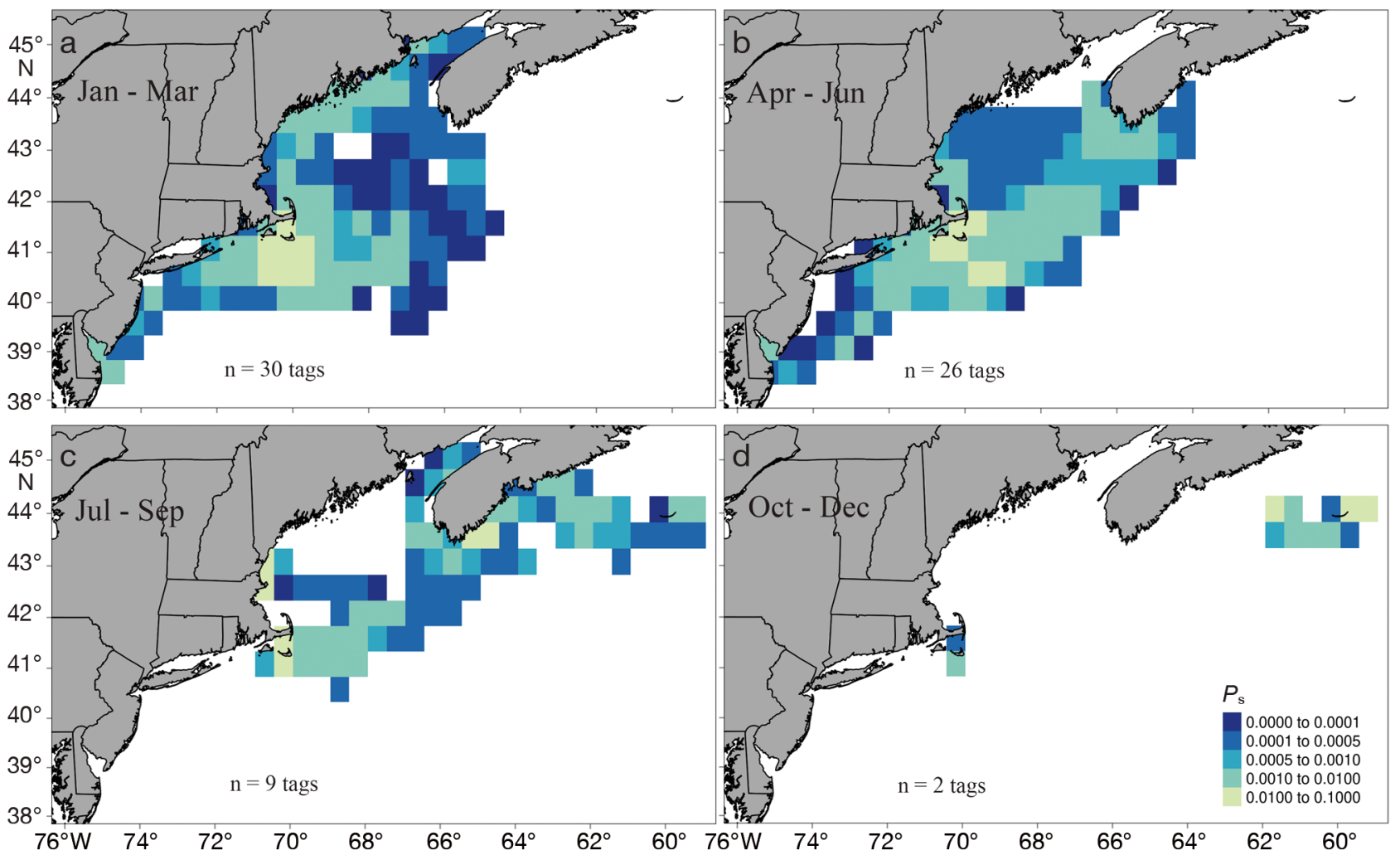

Fig. 2. Seal presence $\left(P_{\mathrm{s}}\right)$ by calendar quarter summarized by 30 min grid cells. (a) January to March; (b) April to June; (c) July to September; (d) October to December. $P_{\mathrm{s}}$ is the relative probability that a seal occupies a grid cell in each quarter relative to all other cells and quarters. The number of satellite tags still transmitting each quarter is also shown

\subsection{Commercial gillnet effort}

The intensity of large-mesh sink gillnet effort varied spatially and temporally throughout the Gulf of Maine and Mid-Atlantic (Fig. 3). Areas of high effort occurred off Cape Cod from April to December, and in southern New England from April to June. There was relatively little effort in coastal regions of Maine for most months.

\subsection{Seals and fishing effort overlap}

The observed overlap between tagged seals and sink gillnet fishing effort $\left(C_{\mathrm{MH}}=0.1919\right)$ was moderate and statistically significant $(\mathrm{p}<0.01)$. The relative risk of seals encountering gillnet fishing gear was highest to the east and south of Cape Cod from April to June (Fig. 4). Risk was generally lower in the MidAtlantic region, and north of Cape Cod from January to March.

From 2015 to 2019, observers sampled roughly $14 \%$ of large-mesh commercial gillnet effort each quarter, averaged over all grid cells. There was a significant relationship between bycatch rates and encounter risk level ( $\tau=0.35,95 \%$ CI: 0.19-0.50, $\mathrm{p}<0.01$ ). Levels of encounter risk aligned fairly well with observed bycatch events, particularly from January to June (Fig. 4). In times and areas of high expected encounter risk based on the overlap of seal use and fishing effort, 405 observed bycatch events occurred, compared to 10 observed bycatch events in times and areas of low expected encounter risk (Table 2). With the exception of 1 seal that spent $100 \%$ of its time in a low risk area, the proportion of time that seals spent in high, medium, and low areas did not vary widely across individuals (see Fig. S1 in the Supplement).

\section{DISCUSSION}

This study showed a significant pattern of spatial overlap between young-of-the-year gray seals and sink gillnet fishing effort in the northeast and MidAtlantic regions of the USA. Compared to other studies $\left(C_{\mathrm{MH}}=0.0391\right.$, Cronin et al. 2016), we found a much higher degree of overlap between gray seals 

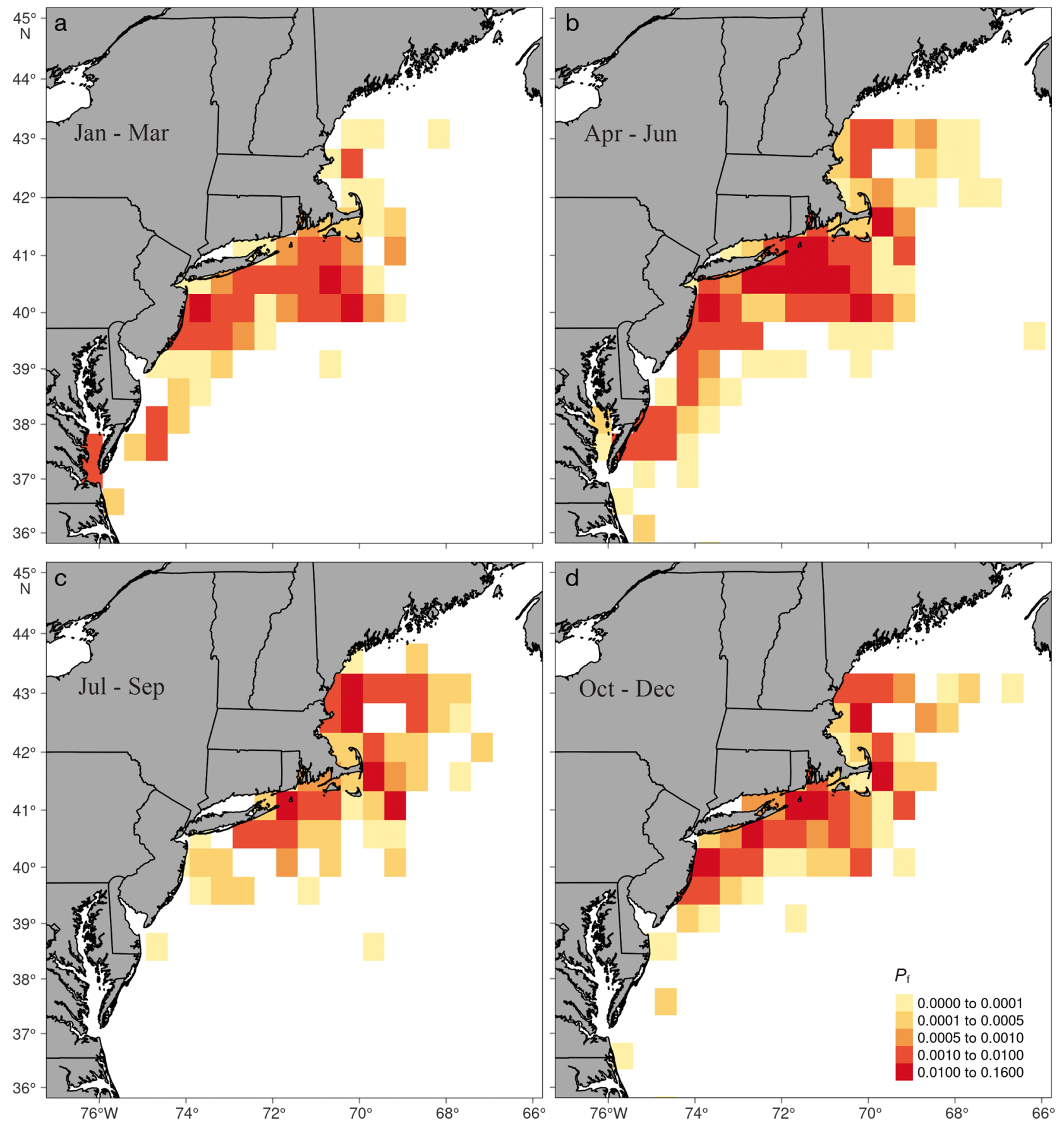

Fig. 3. Large-mesh sink gillnet vessel trip report (VTR) effort $\left(P_{\mathrm{f}}\right)$ by calendar quarter summarized by 30 min grid cells. (a) January to March; (b) April to June; (c) July to September; (d) October to December. $P_{\mathrm{f}}$ is the relative probability that fishing effort (expressed as number of trips) occupies a grid cell in each quarter relative to all other cells and quarters

and a set net fishery; however, that may have been due to the considerably larger grid size examined here. Times and areas of high overlap aligned well with patterns of observed bycatch, indicating spatiotemporal overlap of seal use and fishery effort was a good indicator of bycatch risk. With the exception of 1 seal, most seals spent similar proportions of time in high, medium, and low risk areas, suggesting that the significant overlap was not due to a few seals using the same area (Fig. S1). The highest areas of risk are adjacent to major pupping colonies (Wood et al. 2020) and areas where a high number of gray seals congregate to molt in the spring (Pace et al. 2019). 

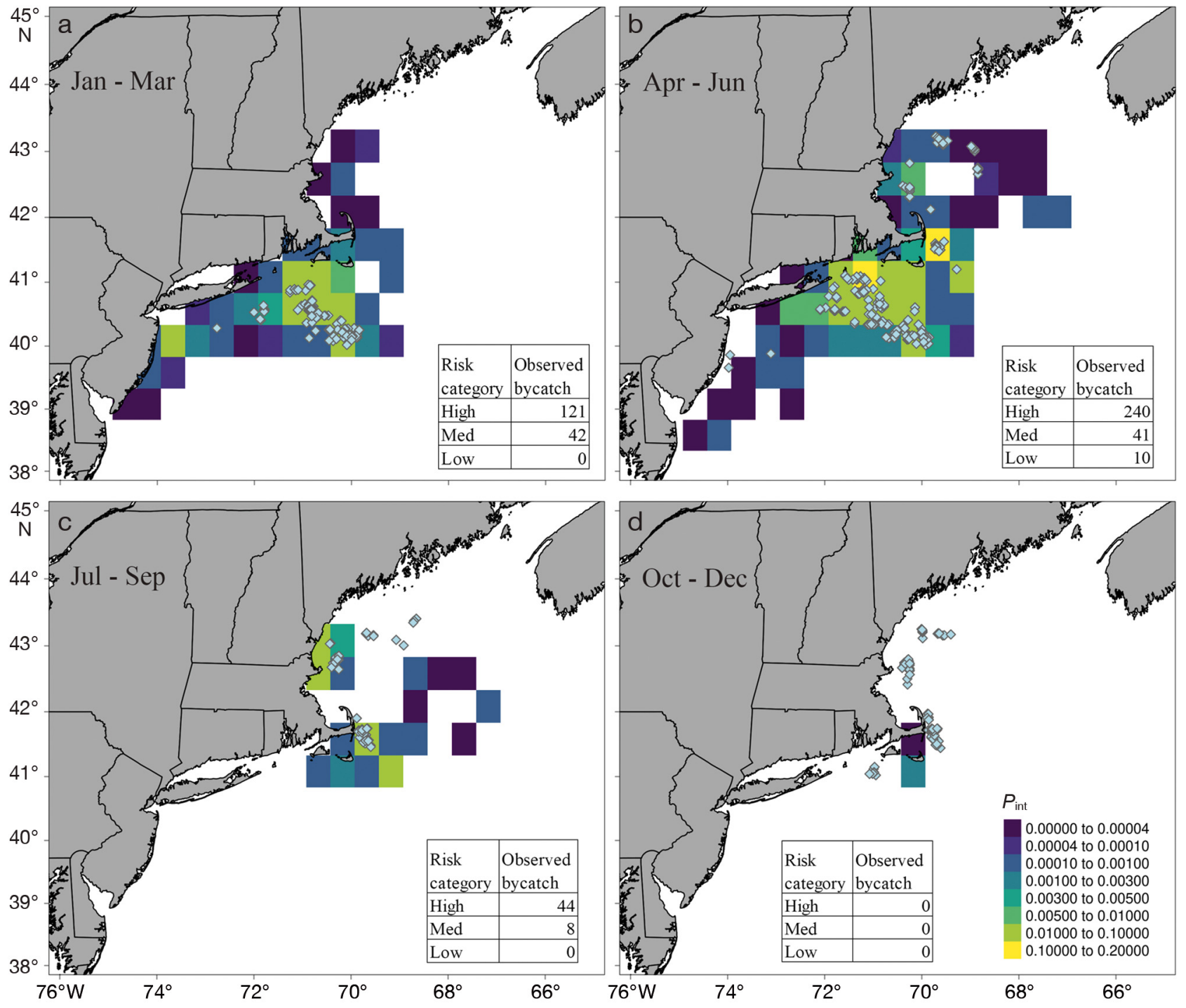

Fig. 4. Risk of seal-fisheries encounter $\left(P_{\text {int }}\right)$ by calendar quarter summarized by 30 min grid cells, color coded to reflect high $\left(P_{\text {int }}>0.003\right)$, medium $\left(0.00004>P_{\text {int }} \leq 0.003\right)$, and low $\left(P_{\text {int }} \leq 0.00004\right)$ encounter risk. (a) January to March; (b) April to June; (c) July to September; (d) October to December. $P_{\text {int }}$ is the relative probability that fishing effort and seals overlap in a grid cell in each quarter relative to all other cells and quarters. Observed bycatch events $(\diamond)$ are overlaid on predicted encounter risk and summarized within each risk category each quarter

Results of this study can help guide further research about bycatch reduction of gray seals in sink gillnet gear. We focused on the large-mesh gillnet fishery because this fishing fleet had the most documented interactions with gray seals, and this helped to reduce variation in potentially influential gear characteristics when comparing across all commercial gillnet trips. Operational characteristics of those trips, such as net length, net height, fishing depth, and soak time, may also influence the likelihood that gray seals encounter gillnets. The large-mesh sink gillnet fishery typically targets just a few species $(93 \%$ of trips were catching monkfish Lophius americanus and skates Rajidae spp.), and there may be particular techniques used to target those species that influence bycatch of young gray seals. For instance, a disproportional amount of bycatch of great shearwater Puffinus gravis occurs in the New England sink gillnet fishery targeting spiny dogfish Squalus acanthias, due to the practice of baiting nets with fish carcasses during sets (Hatch et al. 2016). In Ireland, gray seal bycatch was found to be significantly higher in large-mesh tangle net fisheries for monkfish and could be mitigated with improved net visibility and use of smaller mesh size (Cosgrove et al. 2016). Further research on the operational aspects of trips that 
Table 2. Validation of estimated encounter risk. For each level of encounter risk predicted from the overlap of fishing effort and seal presence, the amount of documented gray seal bycatch in large-mesh sink gillnets from 2015-2019 is shown, as well as the number of observed trips and level of observer coverage (expressed as the proportion of commercial trips that were observed)

\begin{tabular}{|lccc|}
\hline & $\begin{array}{c}\text { High } \\
\text { encounter } \\
\text { risk } \\
\left(P_{\text {rel }}>0.003\right)\end{array}$ & $\begin{array}{c}\text { Medium } \\
\text { encounter } \\
\text { risk } \\
(0.00004> \\
\left.P_{\text {rel }} \leq 0.003\right)\end{array}$ & $\begin{array}{c}\text { Low } \\
\text { encounter } \\
\text { risk } \\
\left(P_{\text {rel }} \leq 0.0004\right)\end{array}$ \\
\hline $\begin{array}{l}\text { Number of } \\
\text { observed } \\
\text { bycatch events } \\
\begin{array}{c}\text { Number of } \\
\text { observed trips } \\
\% \text { observer } \\
\text { coverage (trips) }\end{array}\end{array}$ 1366 & 405 & 91 & 10 \\
\hline
\end{tabular}

influence gray seal bycatch in New England's largemesh sink gillnet fishery may provide ideas for testing gear or fishing practice modifications to reduce bycatch. Fishermen who operate in high-risk areas could offer insight on the dynamics of seal bycatch and suggest techniques to test for bycatch avoidance, as well as their incentives for using any bycatch reduction technology (Campbell \& Cornwell 2008).

Further research is also needed on the behavior of animals around fishing gear and how this may play a role in the probability of encounter. For instance, many trips targeting monkfish use tie-downs, where the head rope is partially tied down to create a pocket in the net. Cameras on the gear might illuminate whether young seals use this pocket to forage and if it contributes to entanglement. More research is also needed on diving and foraging behavior of pups to understand vertical habitat use of gray seals and how that relates to susceptibility to bycatch.

Identifying times and areas of high encounter risk can help prioritize efforts for monitoring protected species bycatch. For instance, high or medium encounter risk was predicted in 1 particular grid cell south of Nantucket in all quarters, yet this area only had observer coverage in quarter 1 . Using encounter risk as a proxy for bycatch may also help supplement existing fisheries monitoring platforms where observer coverage is low or perhaps insufficient to measure protected species bycatch. In some US fisheries, electronic video monitoring will replace human observers as a means to monitor fish catch (www.nefmc.org/ library/amendment-23). Protected species bycatch, however, occurs infrequently and may be unobserved unless video footage is reviewed completely. To avoid unobserved bycatch of protected species, monitoring footage collected from vessels fishing in high risk areas could be fully reviewed to ensure bycatch events are not missed.

Our ability to evaluate encounter risk was slightly reduced because of data limitations, both from an observer coverage perspective and also from the small sample size of satellite-tagged gray seals. Gaps in observer coverage precluded our ability to validate all cells containing predicted encounter risk, with around $20 \%$ of the grids averaged over all quarters lacking validation data. Conversely, bycatch occurred in areas without predicted encounter risk because of a lack of use observed in telemetry data. In particular, the 4 th calendar quarter would improve with changes to telemetry deployments, either in time of year deployed, adjustments to tag programming/transmission settings, and/or additional tagging of more individuals. Species distribution models based on increased tag distribution data should improve understanding of habitat use in a changing environment, which could then be used to improve assessments of bycatch risk (Stock et al. 2020).

Increasing rates of pupping at US colonies (Wood et al. 2020) suggest gray seal population growth is not dampened by observed levels of bycatch in the sink gillnet fishery. However, these high rates of increase - which are as high as $26 \%$ at one colony are likely a result of immigration. A similar situation exists in Irish waters, where levels of bycatch in tangle net fisheries are not negatively impacting gray seals at a population level, due to immigration from adjacent colonies (Cosgrove et al. 2016). If rates of immigration slow, the effect of sustained high levels of bycatch on the US gray seal population may become more pronounced. However, if gray seals continue to expand and fishing effort remains focused on areas near major haul-out sites, bycatch is expected to increase and pose further economic costs to the fishery. Incentives for reducing these costs can prompt the development and testing of mitigation measures. Anticipating continued seal-fishery conflicts, such mitigation strategies will need to be monitored and updated continuously to incorporate new information (Guerra 2019).

\section{CONCLUSION}

Telemetry data is a useful tool to characterize the spatial overlap between a species' habitat use and 
anthropogenic threats like fishing bycatch. Here we intersected movement data from tagged gray seals with seasonal distributions of commercial fishing effort to predict seal-fishery encounters. Resulting probabilities of encounter risk were then validated with fishery-dependent observations of bycatch events. Results of this work will help monitor and possibly mitigate future interactions between gray seals and the New England sink gillnet fishery, which have become increasingly detrimental to both seals and fishery operations. Future work on bycatch risk assessment could focus on operational and behavioral factors affecting bycatch rates. Further modeling efforts with existing and additional telemetry data can build species distribution models that assess risk more dynamically.

Acknowledgements. The capture and tagging of gray seals wouldn't have been possible without the help of Lynda Doughty, Jon Runstadler, Eric Matzen, Tyler Staples, Fred Wenzel, Benjamin VanDine, Alex Creed, Leah Crowe, Dominique Walk, Megan Ely, Katie Gilbert, Cory Roberts, Matt Wyman, Nick Stillwell, Sean Hayes, Wendy Puryear, Milton Levin, Yvonne Vaillancourt, and Diane Lang. We also thank the many fishery observers and at-sea monitors who documented seal bycatch. We thank NOAA's Office of Science \& Technology and the National Marine Sanctuary Foundation (Contract \#C.2018.216 to AMSEAS) for help funding the satellite tags. Gray seal captures were conducted under MMPA Permit \#21719 issued to the Northeast Fisheries Science Center.

\section{LITERATURE CITED}

Anderson CM, Iverson SA, Black A, Mallory ML, Hedd A, Merkel F, Provencher JF (2018) Modelling demographic impacts of a growing Arctic fishery on a seabird population in Canada and Greenland. Mar Environ Res 142:80-90

Baird RW, Anderson DB, Kratofil MA, Webster DL (2021) Bringing the right fishermen to the table: indices of overlap between endangered false killer whales and nearshore fisheries in Hawaii. Biol Conserv 255:108975

* Bennett KA, McConnell BJ, Moss SEW, Speakman JR, Pomeroy PP, Fedak MA (2010) Effects of age and body mass on development of diving capabilities of gray seal pups: costs and benefits of the postweaning fast. Physiol Biochem Zool 83:911-923

* Bowen WD, McMillan J, Mohn R (2003) Sustained exponential population growth of grey seals at Sable Island, Nova Scotia. ICES J Mar Sci 60:1265-1274

* Cahalan J, Faunce C (2020) Development and implementation of a fully randomized sampling design for a fishery monitoring program. Fish Bull 118:87-99

Campbell LM, Cornwell ML (2008) Human dimensions of bycatch reduction technology: current assumptions and directions for future research. Endang Species Res 5: 325-334

Carretta JV, Forney KA, Oleson EM, Weller DW and others (2020) US Pacific marine mammal stock assessments: 2019. US Department of Commerce, NOAA Technical Memorandum NMFS-SWFSC-629
Cook TC, James K, Bearzi M (2015) Angler perceptions of California sea lion (Zalophus californianus) depredation and marine policy in Southern California. Mar Policy 51: 573-583

K Cosgrove R, Gosch M, Reid D, Sheridan M, Chopin N, Jessopp M, Cronin M (2015) Seal depredation in bottom-set gillnet and entangling net fisheries in Irish waters. Fish Res 172:335-344

Cosgrove R, Gosch M, Reid D, Sheridan M, Chopin N, Jessopp M, Cronin M (2016) Seal bycatch in gillnet and entangling net fisheries in Irish waters. Fish Res 183: 192-199

Cronin M, Gerritsen H, Reid D, Jessopp M (2016) Spatial overlap of grey seals and fisheries in Irish waters, some new insights using telemetry technology and VMS. PLOS ONE 11:e0160564

* Curtis KA, Carretta JV (2020) ObsCovgTools: assessing observer coverage needed to document and estimate rate event bycatch. Fish Res 225:105493

* den Heyer CE, Bowen WD, Dale J, Gosselin JF and others (2021) Contrasting trends in gray seal (Halichoerus grypus) pup production throughout the increasing northwest Atlantic metapopulation. Mar Mamm Sci 37:611-630

Fedak MA, Anderson SS (1982) The energetics of lactation: accurate measurements from a large wild mammal, the grey seal (Halichoerus grypus). J Zool 198:473-479

*Gandini P, Frere E (2012) The economic cost of seabird bycatch in Argentinean longline fisheries. Bird Conserv Int 22:59-65

*Gilman E, Clarke S, Brothers N, Alfaro-Shigueto J and others (2008) Shark interactions in pelagic longline fisheries. Mar Policy 32:1-18

Goldsworthy SD, Page B (2007) A risk-assessment approach to evaluation the significance of seal bycatch in two Australian fisheries. Biol Conserv 139:269-285

*Gech A, March H, Coles R (2008) A spatial assessment of the risk to a mobile marine mammal from bycatch. Aquat Conserv 18:1127-1139

Gruber CP (2014) Social, economic, and spatial perceptions of gray seal (Halichoerus grypus) interactions with commercial fisheries in Cape Cod, MA. MSc dissertation, Duke University, Durham, NC

*Guerra AS (2019) Wolves of the sea: managing humanwildlife conflict in an increasingly tense ocean. Mar Policy 99:369-373

Hatch JM (2018) Comprehensive estimates of seabird-fishery interactions for the US Northeast and mid-Atlantic. Aquat Conserv 28:182-193

Hatch JM, Wiley D, Murray KT, Welch L (2016) Integrating satellite-tagged seabird and fishery-dependent data: a case study of great shearwaters (Puffinus gravis) and the US New England sink gillnet fishery. Conserv Lett 9:43-50

Hayes SA, Josephson E, Maze-Foley K, Rosel PE (2019) US Atlantic and Gulf of Mexico marine mammal stock assessments - 2018. NOAA Technical Memorandum NMFSNE-258, US Department of Commerce, Woods Hole, MA

Kohnson DS, London JM, Lea M, Durban JW (2008) Continuous-time correlated random walk model for animal telemetry data. Ecology 89:1208-1215

* Johnston DW, Frungillo J, Smith A, Moore K, Sharp B, Schuh J, Read AJ (2015) Trends in stranding and bycatch rates of gray and harbor seals along the northeastern coast of the United States: evidence of divergence in the abundance of two sympatric phocid species? PLOS ONE 10:e0131660 
Kauppinen T, Siira A, Suuronen P (2005) Temporal and regional patterns in seal-induced catch and gear damage in the coastal trap-net fishery in the northern Baltic Sea: effect of netting material on damage. Fish Res 73:99-109

Königson S, Fjälling A, Berglind M, Lunnerd SG (2013) Male gray seals specialize in raiding salmon traps. Fish Res 148:117-123

Larson SD, Hoyt ZN, Eckert GL, Gill VA (2013) Impacts of sea otter (Enhydra lutris) predation on commercially important sea cucumbers (Parastichopus californicus) in southeast Alaska. Can J Fish Aquat Sci 70:1498-1507

Kewison RL, Crowder LB, Read AJ, Freeman SA (2004) Understanding impacts of fisheries bycatch in marine megafauna. Trends Ecol Evol 19:598-604

Martins MCI, Sette L, Josephson E, Bogomolni A and others (2019) Unoccupied aerial system assessment of entanglement in Northwest Atlantic gray seals (Halichoerus grypus). Mar Mamm Sci 35:1613-1624

McConnell BJ, Chambers C, Fedak MA (1992) Foraging ecology of southern elephant seals in relation to bathymetry and productivity of the Southern Ocean. Antarct Sci 4:393-398

Moore JE, Wallace BP, Lewison RL, Zydelis R, Cox TM, Crowder LB (2009) A review of marine mammal, sea turtle, and seabird bycatch in USA fisheries and the role of policy in shaping management. Mar Policy 33:435-451

Murray KT (2009) Characteristics and magnitude of sea turtle bycatch in US mid-Atlantic gillnet gear. Endang Species Res 8:211-224

Murray KT, Orphanides CD (2013) Estimating the risk of loggerhead turtle Caretta caretta bycatch in the US midAtlantic using fishery-independent and -dependent data. Mar Ecol Prog Ser 477:259-270

Muto MM, Helker VT, Delean BJ, Angliss RP and others (2020) Alaska marine mammal stock assessments, 2019. NOAA Technical Memorandum NMFS-AFSC-404, US Department of Commerce, Woods Hole, MA

Olsen MT, Galatius A, Härkönen T (2018) The history and effects of seal-fishery conflicts in Denmark. Mar Ecol Prog Ser 595:233-243

Orphanides CD (2019) Estimates of cetacean and pinniped bycatch in the 2016 New England sink and mid-Atlantic gillnet fisheries. Northeast Fish Sci Cent Ref Doc 19-04

Orphanides CD (2020) Estimates of cetacean and pinniped bycatch in the 2017 New England sink and midAtlantic gillnet fisheries. Northeast Fish Sci Cent Ref Doc 20-03

Orphanides CD, Hatch J (2017) Estimates of cetacean and pinniped bycatch in the 2015 New England sink and mid-Atlantic gillnet fisheries. Northeast Fish Sci Cent Ref Doc 17-18

Pace RM, Josephson E, Wood SA, Murray K, Waring G (2019) Trends and patterns of seal abundance at haul-out

Editorial responsibility: Kyle Elliott,

Sainte-Anne-de-Bellevue, Québec, Canada

Reviewed by: J. Hall Moxley, A. Bjørge and 1 anonymous

referee sites in a gray seal recolonization zone. NOAA Technical Memorandum NMFS-NE-251, US Department of Commerce, Woods Hole, MA

* Peterson MJ, Carothers C (2013) Whale interactions with Alaskan sablefish and Pacific halibut fisheries: surveying fishermen perception, changing fishing practices and mitigation. Mar Policy 42:315-324

Rafferty AR, Brazer EO Jr, Reina RD (2012) Depredation by harbor seal and spiny dogfish in a Georges Bank gillnet fishery. Fish Manag Ecol 19:264-272

Roe JH, Morreale SJ, Paladino FV, Shillinger GL and others (2014) Predicting bycatch hotspots for endangered leatherback turtles on longlines in the Pacific Ocean. Proc R Soc B 281:20132559

Rossman MC (2010) Estimating bycatch of small cetaceans in northeast US bottom trawl fishing gear during 2000-2005. J Northwest Atl Fish Sci 42:77-101

Stepanuk JE, Read AJ, Baird RW, Webster DL, Thorne LH (2018) Spatiotemporal patterns of overlap between short-finned pilot whales and the US pelagic longline fishery in the Mid-Atlantic Bight: an assessment to inform the management of fisheries bycatch. Fish Res 208:309-320

Stock BC, Ward EJ, Eguchi T, Jannot JE, Thorson JT, Feist BE, Semmens BX (2020) Comparing predictions of fisheries bycatch using multiple spatiotemporal species distribution model frameworks. Can J Fish Aquat Sci 77: 146-163

พ Tixier P, Lea M, Hindell MA, Welsford D, Mazé C, Gourguet S, Arnould JPY (2021) When large marine predators feed on fisheries catches: global patterns of the depredation conflict and directions for coexistence. Fish Fish 22: $31-53$

*Vincent C, McConnell BJ, Ridoux V, Fedak MA (2002) Assessment of Argos location accuracy from satellite tags deployed on captive grey seals. Mar Mamm Sci 18: 156-166

*Wallace BP, Heppell SS, Lewison RL, Kelez S, Crowder LB (2008) Impacts of fisheries bycatch on loggerhead turtles worldwide inferred from reproductive value analyses. J Appl Ecol 45:1076-1085

*Warden ML (2011) Modeling loggerhead sea turtle (Caretta caretta) interactions with US Mid-Atlantic bottom trawl gear for fish and scallops, 2005-2008. Biol Conserv 144: 2202-2212

WWood SA, Frasier TR, McLeod BA, Gilbert JR and others (2011) The genetics of recolonization: an analysis of the stock structure of grey seals (Halichoerus grypus) in the Northwest Atlantic. Can J Zool 89:490-497

* Wood SA, Murray KT, Josephson E, Gilbert J (2020) Rates of increase in gray seal (Halichoerus grypus atlantica) pupping at recolonized sites in the United States, 1988-2019. J Mammal 101:121-128

Submitted: January 27, 2021

Accepted: May 25, 2021

Proofs received from author(s): July 30, 2021 